\title{
The novel immunomodulator IMMUNEPOTENT CRP combined with chemotherapy agent increased the rate of immunogenic cell death and prevented melanoma growth
}

\author{
MARIA DEL CARMEN RODRÍGUEZ-SALAZAR ${ }^{1 *}$, MOISES ARMIDES FRANCO-MOLINA ${ }^{1 *}$, \\ EDGAR MENDOZA-GAMBOA ${ }^{1}$, ANA CAROLINA MARTÍNEZ-TORRES ${ }^{1}$, \\ PABLO ZAPATA-BENAVIDES ${ }^{1}$, JOSE SULLIVAN LÓPEZ-GONZÁLEZ ${ }^{2}$, \\ ERIKA EVANGELINA CORONADO-CERDA ${ }^{1}$, JUAN MANUEL ALCOCER-GONZÁLEZ ${ }^{1}$, \\ REYES SILVESTRE TAMEZ-GUERRA ${ }^{1}$ and CRISTINA RODRÍGUEZ-PADILLA ${ }^{1}$ \\ ${ }^{1}$ Department of Immunology and Virology, Biological Sciences Faculty, \\ Autonomous University of Nuevo Leon, San Nicolas de los Garza, Nuevo Leon 66455; \\ ${ }^{2}$ Lung Cancer Laboratory, National Institute of Respiratory Diseases 'Ismael Cosio Villegas', Mexico City 14080, Mexico
}

Received April 8, 2016; Accepted March 28, 2017

DOI: $10.3892 / \mathrm{ol} .2017 .6202$

\begin{abstract}
Immunogenic cell death is a cell death modality that stimulates the immune system to combat cancer cells. IMMUNEPOTENT CRP (ICRP) is a mixture of substances of low molecular weight obtained from bovine spleens that exhibits in vitro cytotoxic activity on different tumor cell lines and modulates the immune response in vivo. The aim of the present study was to determine whether the cytotoxic effect of ICRP and its combination with oxaliplatin (OXP) on murine melanoma B16F10 cells was due to immunogenic cell death. The cytotoxic assay was performed using flow cytometry to detect Annexin V and propidium iodide staining, and calreticulin (CRT) exposure. Adenosine triphosphate, heat shock protein (HSP) 70, HSP90 and high mobility group box 1 (HMGB1) release were identified using bioluminescence, western blot and ELISA assays, respectively. The present in vitro study demonstrated that treatments with ICRP or OXP induced cell death in a time-dependent manner, but treatment with the combination of ICRP + OXP increased the cytotoxic effect following $24 \mathrm{~h}$ of treatment. CRT exposure and release of adenosine triphosphate (ATP), HSP70, HSP90 and HMGB1 were induced by treatment with ICRP, and the
\end{abstract}

Correspondence to: Dr Reyes Silvestre Tamez-Guerra, Department of Immunology and Virology, Biological Sciences Faculty, Autonomous University of Nuevo Leon, Avenue Pedro de Alba s/n, PO Box 46 F, San Nicolas de los Garza, Nuevo Leon 66455, Mexico

E-mail: rtamezguerra@gmail.com

*Contributed equally

Key words: immunogenic cell death, damage-associated molecular patterns, melanoma, IMMUNEPOTENT CRP, oxaliplatin combination of ICRP + OXP increased the exposure and release of damage-associated molecular patterns (DAMPs), while OXP treatment only induced CRT exposure, ATP and HMGB1 release. The in vivo experiments demonstrated that administration of tumor-derived DAMP-rich cell lysates derived from B16F10 cells treated with ICRP and the combination of ICRP + OXP prevented melanoma growth; however, OXP treatment did not. These results suggested that IMMUNEPOTENT CRP may be used as an agent to increase the ability of antitumor drugs to induce immunogenic cell death and prevent the growth of melanoma.

\section{Introduction}

Immunogenic death is a cell death modality that stimulates the innate and adaptive immune system against cell death associated antigens, inducing tumor cell immunogenicity. Immunogenic cell death (ICD) is characterized by the exposure or release of immunogenic molecules by dying tumor cells (1-3), termed damage-associated molecular patterns (DAMPs). Certain DAMPs include calreticulin (CRT) exposure on the outer surface of the plasma membrane, which serves an important function as a phagocytic signal, stimulating phagocytes to engulf dead tumor cells $(3,4-8)$. The secretion of adenosine triphosphate (ATP) by dying tumor cells is an important chemoattractant for macrophages and dendritic cells to the site of tumor (3,9-13). The heat shock proteins (HSP) 70 and HSP90, and non-histone chromatin binding protein high mobility group box 1 (HMGB1) are released into the extracellular space and promote the recognition of tumor cells by dendritic cells by binding to receptors on the cell surface, leading to their elimination by the immune system (14-19).

It has been suggested that only certain types of cancer therapies induce immunogenic cell death in vitro (20-23) and in vivo (5,24-29), and that these may be classified into two groups. The targets of group I ICD inducers include DNA 
and repair machinery proteins, cytosolic proteins, plasma membrane or nucleic proteins, which are targeted by chemotherapeutic agents including anthracyclines, oxaliplatin (OXP) and mitoxantrone; cardiac glycosides, shikonin and ultraviolet $\mathrm{C}$ irradiation. Group II ICD inducers target the endoplasmic reticulum, and include photodynamic therapy with hypericin and Coxsackievirus B3 (8,30-34). Certain ICD agents with these characteristics are considered to be anti-cancer vaccines, and as therapies that prevent residual cancer.

IMMUNEPOTENT CRP (ICRP) is a dialysate of a heterogeneous mixture of low-molecular-weight substances released from the disintegrated leukocytes of the blood or lymphoid tissue obtained from homogenized bovine spleens. ICRP exhibits in vitro cytotoxic effects on different tumor cell lines and modulates the immune response in vivo (35-40). The aim of the present study was to determine whether ICRP or ICRP combined with OXP induced ICD and prevented melanoma growth.

\section{Materials and methods}

Reagents and antibodies. OXP was obtained from Teva Pharmaceutical Industries, Ltd. (Petah Tikva, Israel). IMMUNEPOTENT CRP was produced by the Department of Immunology and Virology, Biological Sciences Faculty, Autonomous University of Nuevo Leon (Nuevo Leon, Mexico). Propidium iodide staining solution and allophycocyanin (APC)-conjugated Annexin V was obtained from BD Pharmingen (BD Biosciences, San Jose, CA, USA). Phycoerythin (PE)-conjugated CRT monoclonal antibodies (cat. no. ADI-SPA-601PE-F) and IgG1 isotype control monoclonal antibodies (cat. no. ADI-SAB-600PE-D) were obtained from Enzo Life Sciences (Farmingdale, NY, USA). Mouse monoclonal antibodies targeting HSP70 (cat. no. sc-24), HMGB1 (cat. no. sc-56698), $\beta$-actin (cat. no. sc-69879), rabbit polyclonal IgG antibody targeting HSP90 $\alpha / \beta$ (cat. no. sc-7947), and secondary antibodies including mouse anti-rabbit (cat. no. sc-2357) and goat anti-mouse (cat. no. sc-2005) IgGs conjugated to horseradish peroxidase were obtained from Santa Cruz Biotechnology, Inc. (Dallas, TX, USA). Complete Halt Protease inhibitor cocktail (100X) was obtained from Thermo Fisher Scientific, Inc. (cat. no. 87786; Waltham, MA, USA). The ENLITEN ATP Assay System Bioluminescence Detection kit for ATP measurement was obtained from Promega Corporation (Madison, WI, USA). The HMGB1 BioAssay ELISA kit (mouse; cat. no. 194487) was purchased from US Biological Life Sciences (Salem, MA, USA).

Cell line and culture conditions. The murine melanoma B16F10 cell line was obtained from American Type Tissue Collection (Manassas, VA, USA) and was maintained in Dulbecco's modified Eagle's medium/F-12 medium 1:1 containing $2.50 \mathrm{mM}$ L-Glutamine, $15 \mathrm{mM}$ 4-(2-hydroxyethyl)-1-piperazineethanesulfonic acid buffer medium (cat. no. SH30023.FS; all HyClone; GE Healthcare Life Sciences, Logan, UT, USA) supplemented with $10 \%$ heat-inactivated fetal bovine serum (cat. no. 10082147) and $100 \mathrm{U} / \mathrm{ml}$ penicillin/streptomycin (cat. no. 15140122; both Gibco; Thermo Fisher Scientific, Inc.). The cell line was incubated in a humidified atmosphere with $5 \% \mathrm{CO}_{2}$ at $37^{\circ} \mathrm{C}$.
Cell death assays. B16F10 cells $\left(1 \times 10^{5}\right)$ were seeded into 12 -well plates and cultured overnight in $5 \% \mathrm{CO}_{2}$ at $37^{\circ} \mathrm{C}$. Cells were treated with ICRP $(1 \mathrm{U} / \mathrm{ml}), \mathrm{OXP}(800 \mu \mathrm{M})$ or a combination of ICRP $(1 \mathrm{U} / \mathrm{ml})+\operatorname{OXP}(800 \mu \mathrm{M})$ for 24,48 and $72 \mathrm{~h}$. Following treatment, cells were collected and washed with phosphate-buffered saline (PBS) and resuspended in $100 \mu \mathrm{l}$ of $1 \mathrm{X}$ binding buffer $(0.1 \mathrm{M}$ Hepes $\mathrm{pH} 7.4,1.4 \mathrm{M} \mathrm{NaCl}$ and $25 \mathrm{mM} \mathrm{CaCl}_{2}$; Sigma-Aldrich; Merck KGaA, Darmstadt, Germany) supplemented with APC-conjugated Annexin V (5 $\mu \mathrm{l} / \mathrm{sample}$ ) and propidium iodide ( $1 \mu \mathrm{l} / \mathrm{sample})$, incubated on ice and kept in the dark for $15 \mathrm{~min}$. Flow cytometry analysis was performed using an Accuri C6 cytometer; BD Accuri C6 Software version 1.0.264.21 was used for data analysis (both BD Biosciences, San Jose, CA, USA).

Analysis of CRT on the cell surface. Flow cytometry was used to determine the level of CRT exposure induced by the treatments. B16F10 cells $\left(1 \times 10^{5}\right)$ were treated with ICRP $(1 \mathrm{U} / \mathrm{ml})$, OXP $(800 \mu \mathrm{M})$ or the combination of ICRP $(1 \mathrm{U} / \mathrm{ml})+$ OXP $(800 \mu \mathrm{M})$ for $6,12,24,48$ or $72 \mathrm{~h}$. The cells were harvested, suspended in $1 \mathrm{X}$ PBS with $1 \%$ fetal bovine serum and incubated for $1 \mathrm{~h}$ at room temperature in the dark with a CRT monoclonal antibody (dilution, 1:100), then analyzed.

Western blot analysis. B16F10 cells $\left(5 \times 10^{6}\right)$ cells were treated with ICRP $(1 \mathrm{U} / \mathrm{ml})$, OXP $(800 \mu \mathrm{M})$ or a combination of ICRP $(1 \mathrm{U} / \mathrm{ml})+\mathrm{OXP}(800 \mu \mathrm{M})$ for 24,48 and 72 h. Following this, supernatants and cells were collected and centrifuged at $260 \mathrm{x} \mathrm{g}$ for $10 \mathrm{~min}$ at room temperature. The cells were washed with PBS and homogenized using the SET 2X lysis buffer (20 mM Tris pH 6.8, 2 mM EDTA pH 8.0, $300 \mathrm{mM}$ $\mathrm{NaCl}$ and 4\% SDS; Sigma-Aldrich; Merck KGaA) supplemented with the Complete Halt protease inhibitor cocktail. Protein quantification was performed using a detergent compatible Lowry protocol protein assay (cat. no. 5000112; Bio-Rad Laboratories, Inc., Hercules, CA, USA). Equal amounts of soluble proteins $(50 \mu \mathrm{g})$ were resolved by $12 \%$ SDS-PAGE and transferred to a nitrocellulose membrane. Non-specific binding sites were blocked by incubating the membrane for $1 \mathrm{~h}$ at room temperature in TBS-Tween-20 supplemented with $5 \%$ non-fat powdered milk followed by overnight incubation at $4{ }^{\circ} \mathrm{C}$ with primary antibodies, including anti-HSP90 or - $\beta$-actin (the internal standard) at a dilution of 1:500, or anti-HSP70 or -HMGB1 at a dilution of 1:400. The antibodies were diluted in $10 \mathrm{ml}$ of $1 \mathrm{X}$ TBS-0.1\% Tween-20 buffer supplemented with 5\% w/v BSA. Primary antibodies were detected by incubation with mouse anti-rabbit or goat anti-mouse IgGs conjugated to horseradish peroxidase, diluted to $1: 2,000$, for $2 \mathrm{~h}$ at room temperature. The protein bands were visualized using an enhanced chemiluminescence western blotting detection kit and high performance chemiluminescence film (both GE Healthcare Life Sciences).

ATP release assays. Extracellular ATP levels were measured in the supernatant of B16F10 cells treated with ICRP $(1 \mathrm{U} / \mathrm{ml})$, OXP $(800 \mu \mathrm{M})$ or a combination of ICRP $(1 \mathrm{U} / \mathrm{ml})+$ OXP $(800 \mu \mathrm{M})$ for 24,48 and $72 \mathrm{~h}$ by luciferin-based ENLITEN ATP assay (Promega Corporation) according to the manufacturer's protocol. Chemiluminescence was recorded with a 


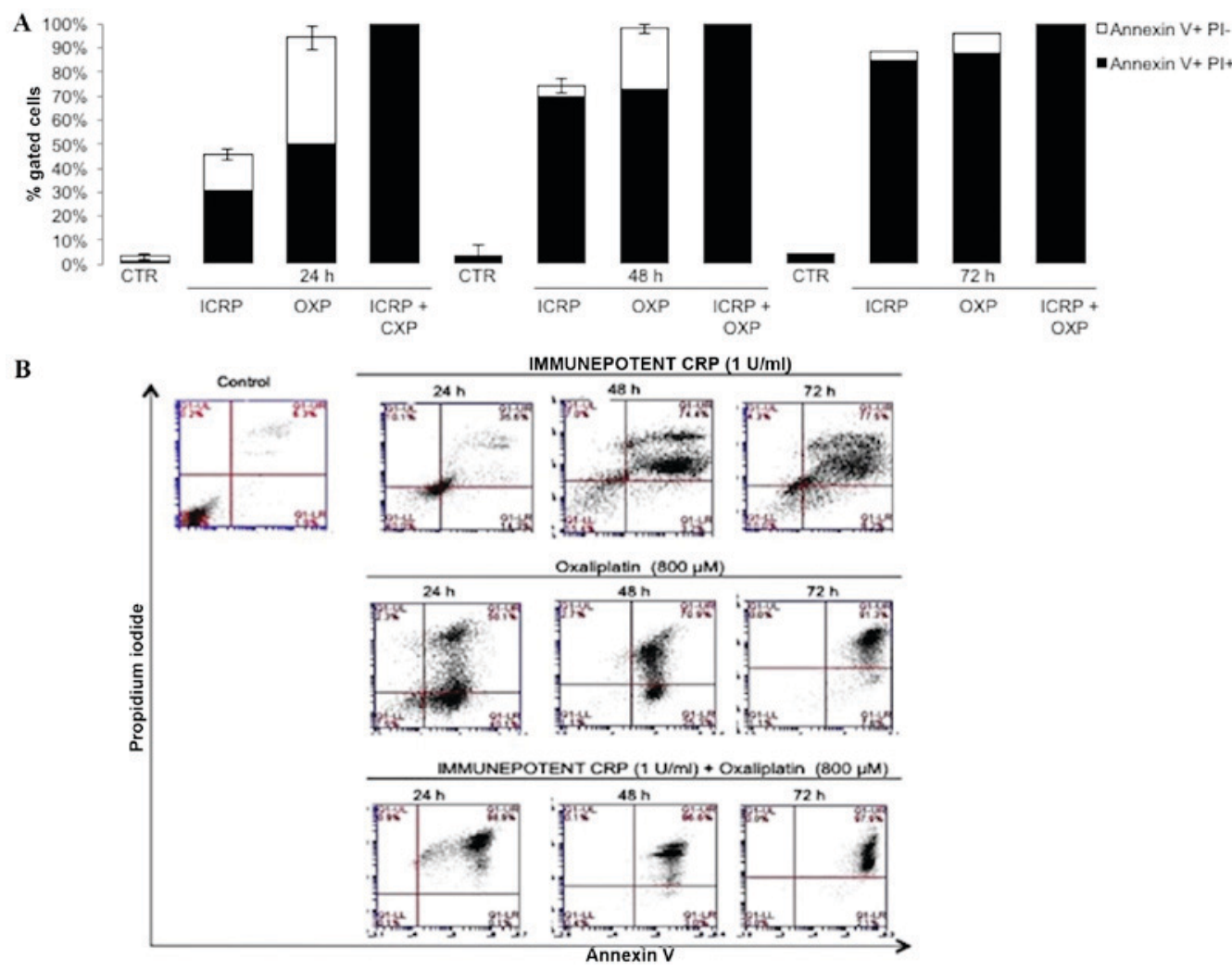

Figure 1. ICRP, OXP and ICRP + OXP treatments induce cell death in B16F10 cells, as assessed by Annexin V-allophycocyanin and PI staining and analyzed by flow cytometry. (A) Representative bar graphs of data obtained via flow cytometry, presented as the mean \pm standard deviation and performed in triplicate. (B) Data are represented as a dot plot. ICRP, IMMUNEPOTENT CRP; OXP, oxaliplatin; PI, propidium iodide; CTR, control.

BioTek Synergy microplate reader (BioTek Instruments, Inc., Winooski, VT, USA).

HMGB1 release assays. HMGB1 concentration was measured in the supernatant of untreated or treated B16F10 cells with ICRP $(1 \mathrm{U} / \mathrm{ml})$, OXP $(800 \mu \mathrm{M})$ and the combination of ICRP $(1 \mathrm{U} / \mathrm{ml})+\mathrm{OXP}(800 \mu \mathrm{M})$ for 24,48 and $72 \mathrm{~h}$ using the HMGB1 ELISA kit according to the manufacturer's protocol.

Animals. A total of 20 female C57BL/6 mice were purchased from Harlan Laboratories (Mexico City, Mexico). The body weight of mice was $23( \pm 2) \mathrm{g}$ and they were between 6 and 10 weeks of age. The mice were housed at $25-29^{\circ} \mathrm{C}$ with $45 \%$ humidity and a $12 \mathrm{~h}$ light: $12 \mathrm{~h}$ dark cycle. Mice were provided food and water ad libitum. According to experimental protocols that were approved by the Ethics Review Committee for Animal Experimentation of the Biological Sciences Faculty, Autonomous University of Nuevo Leon (San Nicolas de los Garza, Mexico).

In vivo anti-tumor vaccination experiments. A total of $5 \times 10^{6} \mathrm{~B} 16 \mathrm{~F} 10$ cells were treated with ICRP $(3 \mathrm{U} / \mathrm{ml})$, OXP $(12,600 \mu \mathrm{M})$ or a combination of ICRP $(1.2 \mathrm{U} / \mathrm{ml})+$ OXP $(900 \mu \mathrm{M})$ for $48 \mathrm{~h}$ in vitro. Following this, the cells were centrifuged at $260 \mathrm{x}$ g for $10 \mathrm{~min}$ and washed twice with PBS. Finally, cells were resuspended in $200 \mu \mathrm{l}$ PBS and inoculated subcutaneously into the left flank of the mice. After 7 days, mice were challenged with $5 \times 10^{5}$ live B16F10 cells resuspended in $200 \mu \mathrm{l}$ of PBS via subcutaneous injection into the right flank. Tumor incidence and growth were measured every day at the two injection sites for 60 days with a digital caliper. Tumor volume was calculated using the formula: $V=(W(2) \times L) / 2$, where $\mathrm{V}$ is tumor volume, $\mathrm{W}$ is tumor width and $\mathrm{L}$ is tumor length.

Humane end-points were used to avoid unnecessary suffering. Mice were sacrificed when the width of tumors reached $20 \mathrm{~mm}$. Effort was made to minimize environmental stress. The control group was sacrificed at 20 days, the OXP group at 30 days, and the ICRP and ICRP + OXP groups at 60 days.

Statistical analysis. The experiments were performed in triplicate and statistical analysis was performed using a one-way analysis of variance followed by Dunnett's test. $\mathrm{P}<0.05$ was considered to indicate a statistically significant difference. SPSS version 17.0 (IBM Corp., Armonk, NY, USA) was used to perform the analysis.

\section{Results}

Cell death is induced by ICRP, OXP or ICRP + OXP treatments in the B16F10 cell line. Treatment with ICRP [24 h $(30.6 \%), 48 \mathrm{~h}(69.6 \%)$, and $72 \mathrm{~h}(85 \%)]$ and OXP [24 h $(50.5 \%), 48 \mathrm{~h}(72.6 \%)$, and $72 \mathrm{~h}(88 \%)]$ induced cell death in a time-dependent manner (Fig. 1A). Treatment with the combination of ICRP + OXP induced a cytotoxic effect at all time-points evaluated [24 h (98.8\%), $48 \mathrm{~h}$ (100\%), and $72 \mathrm{~h}$ (100\%); Fig. 1A]. Apoptosis was indicated by staining with Annexin V-APC, which binds to phosphatidylserine residues on the surface of dying cells, and propidium iodide, which 

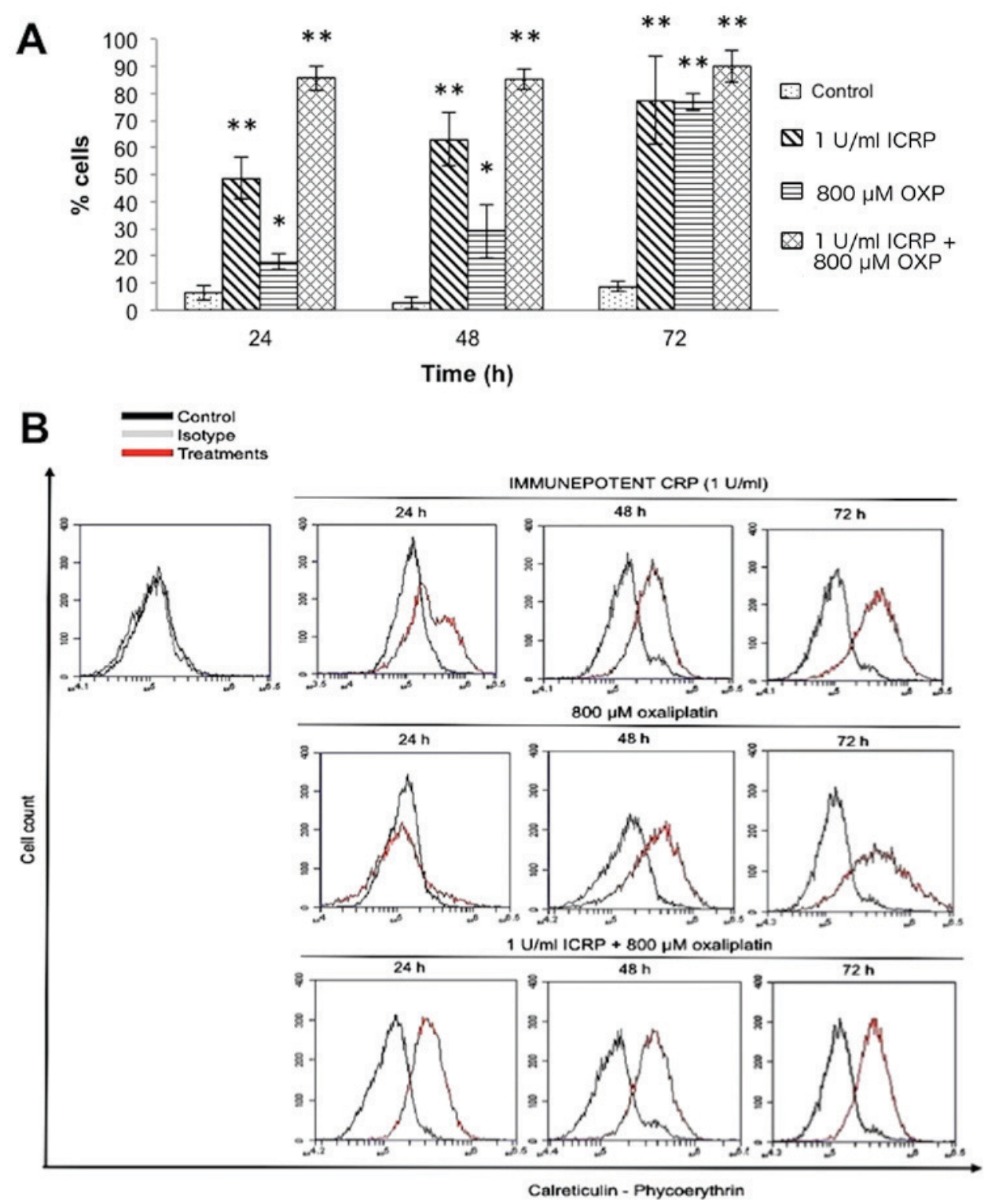

Figure 2. ICRP, OXP and ICRP + OXP treatments induce exposure of calreticulin in B16F10 melanoma cells. Treated cells were stained using anti-calreticulin antibodies and isotype control antibodies conjugated with fluorochrome phycoerythrin and analyzed by flow cytometry. Results are from three independent experiments performed in triplicate, and data are presented as the mean \pm standard deviation. (A) Representative bar graphs of data obtained from flow cytometry. ${ }^{*} \mathrm{P}<0.05,{ }^{* *} \mathrm{P}<0.001$ vs. control. (B) Representative dot plots of the experiment. ICRP, IMMUNEPOTENT CRP; OXP, oxaliplatin.

penetrates only into dead cells (Fig. 1B). In the untreated B16F10 cells, cell viability was not affected.

CRT exposure is induced by treatment with ICRP, OXP or $I C R P+O X P$ in the B16F10 cell line. Treatment with ICRP or OXP induced CRT exposure in a time-dependent manner (ICRP: 6 h, 9.1\%; 12 h, 23\%; 24 h, 48.6\%; 48 h, 63\%; and 72 h, 77.4\%; P<0.001; OXP: 6 h, 2.6\%; 12 h, 9.2\%; 24 h, 17.7\%; 48 h, $29 \%$; and 72 h, 76.8\%; P<0.05; Fig. 2). Treatment with a combination of ICRP + OXP induced the highest exposure of CRT following treatment for $24 \mathrm{~h}$, however, following combined treatment for $6 \mathrm{~h}, \mathrm{CRT}$ exposure was higher compared with the individual treatments $(6 \mathrm{~h}, 12.7 \% ; 12 \mathrm{~h}, 58.2 \% ; 24 \mathrm{~h}, 85.4 \%$; 48 h, $85.10 \%$; and 72 h, $90 \%$; P<0.001; Fig. 2).

Release of ATP in the B16F10 cell line following treatment with ICRP, OXP or ICRP + OXP. The release of ATP significantly increased following $24 \mathrm{~h}$ of treatment with ICRP $(\mathrm{P}<0.05$; Fig. 3$)$ and the combination of ICRP+OXP $(\mathrm{P}<0.001$; Fig. 3). Following $48 \mathrm{~h}$ of treatment, ATP release was not detected except by ICRP treatment at $72 \mathrm{~h}(\mathrm{P}<0.01$; Fig. 3$)$. The decreased ATP detection following $48 \mathrm{~h}$ of treatment may be because extracellular ATP is not stable, due to the presence of various enzymes that degrade ATP (ATPases) or the decomposition of ATP to adenosine diphosphate, adenosine monophosphate, adenosine and inorganic phosphate $(10,13)$.

Release of HSP70, HSP90 and HMGB1 proteins in the B16F10 cell line treated with ICRP, OXP or ICRP $+O X P$. In the supernatant, treatment with ICRP + OXP induced the release of HSP70 and HSP90 in the B16F10 cells at all evaluated time-points, and their release was increased at 48 and $72 \mathrm{~h}$ relative to $24 \mathrm{~h}$. ICRP treatment induced the release of these proteins, and they were detected at $48 \mathrm{~h}$, 


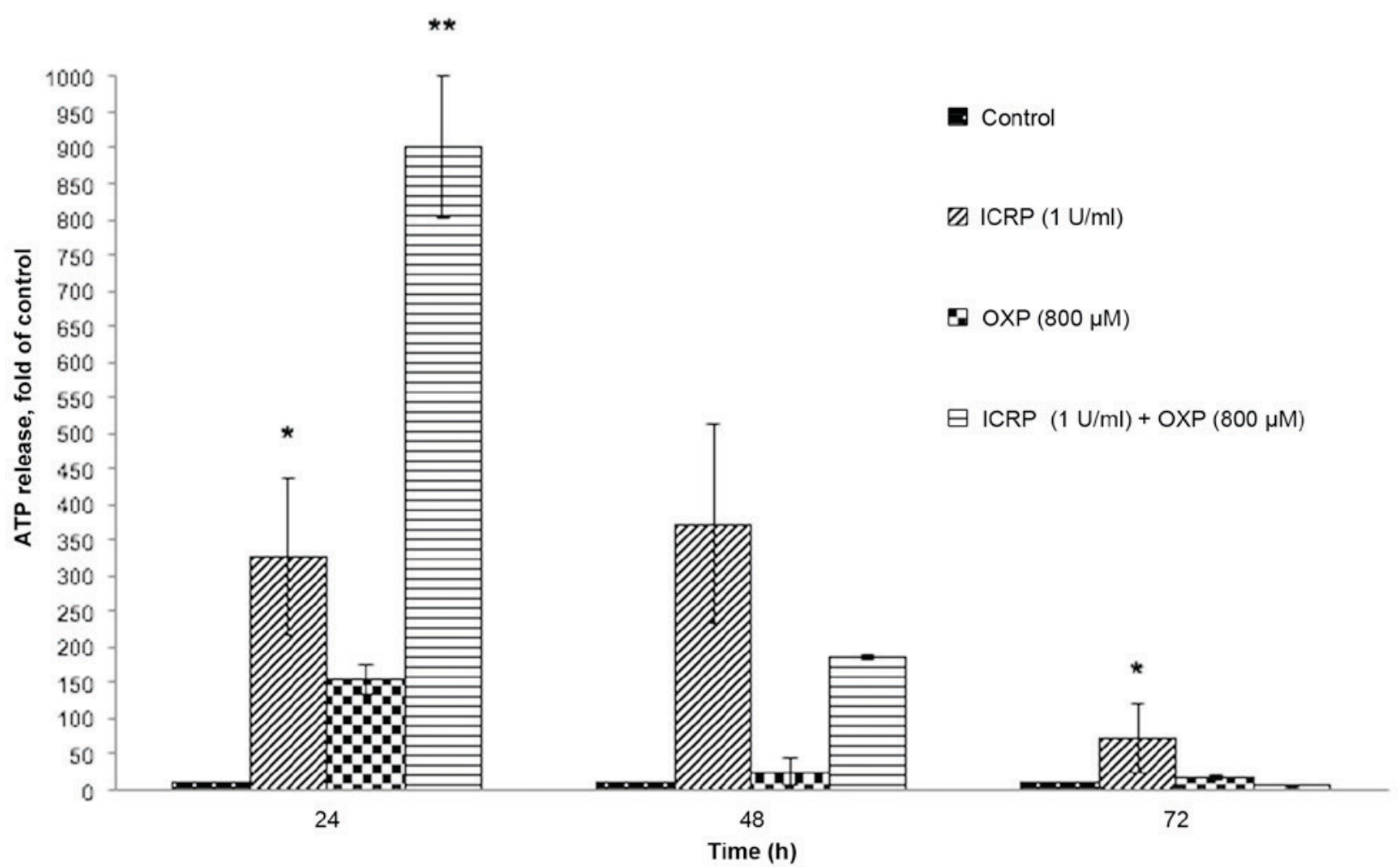

Figure 3. ATP release in response to ICRP, OXP, and ICRP + OXP treatments. ${ }^{*} \mathrm{P}<0.05,{ }^{* *} \mathrm{P}<0.001$ vs. control. ATP, adenosine triphosphate; ICRP, IMMUNEPOTENT CRP; OXP, oxaliplatin.

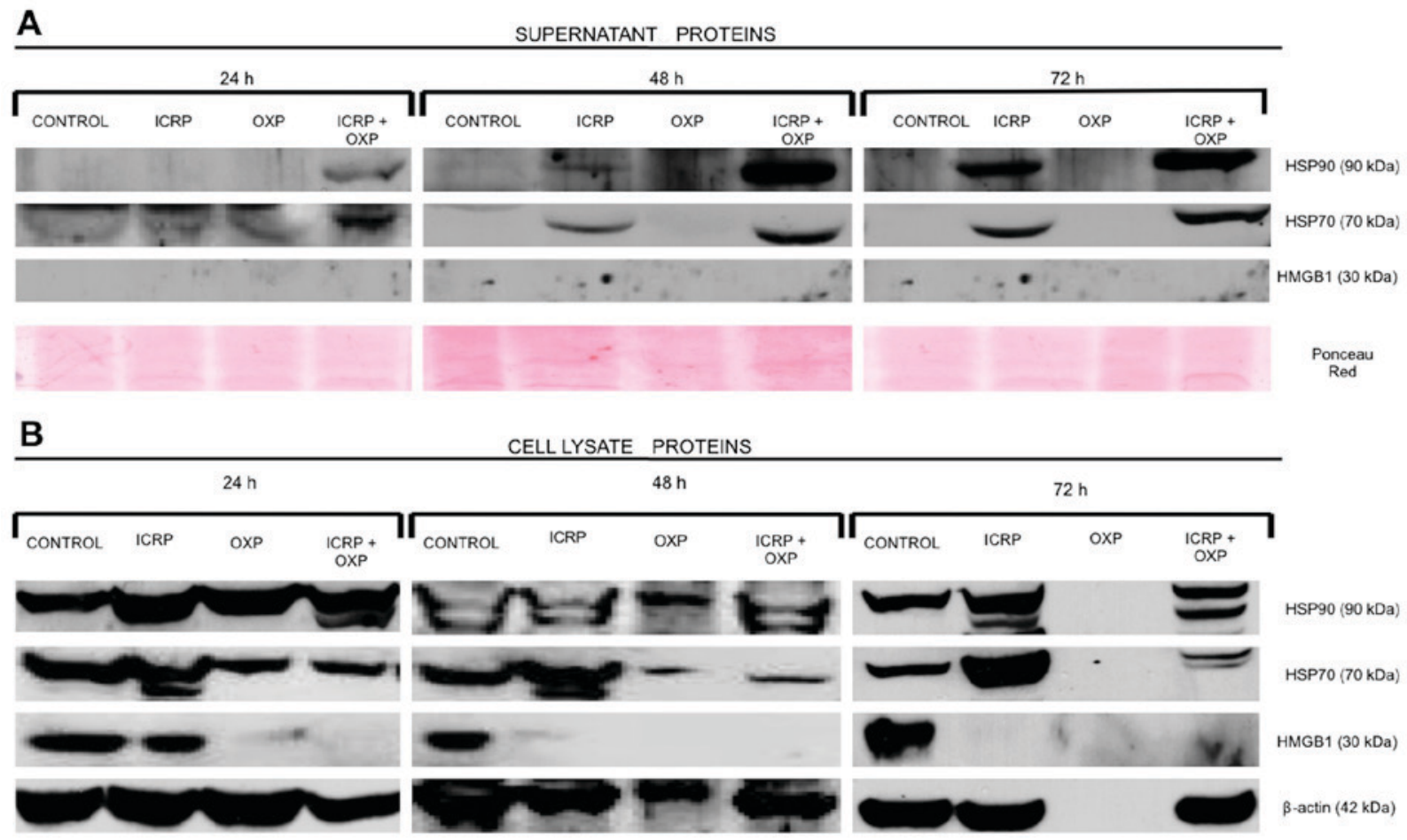

Figure 4. Expression and release of HSP70, HSP90 and HMGB1 proteins in response to treatment with ICRP, OXP, and ICRP + OXP. Western blotting was performed using (A) cell supernatants and (B) whole cell lysates of B16F10 cells. $\beta$-actin was used as a loading control. HSP, heat shock protein; HMGB1, high mobility group box 1; ICRP, IMMUNEPOTENT CRP; OXP, oxaliplatin.

and their release was increased in the supernatants at $72 \mathrm{~h}$ relative to $24 \mathrm{~h}$. OXP did not induce the release of HSP70 or HSP90 at any of the evaluated time-points. HMGB1 was not detected in any of the treatments by western blotting (Fig. 4). Therefore, an ELISA kit with high sensitivity was used for its detection, and it was revealed that all ICRP, OXP or ICRP 


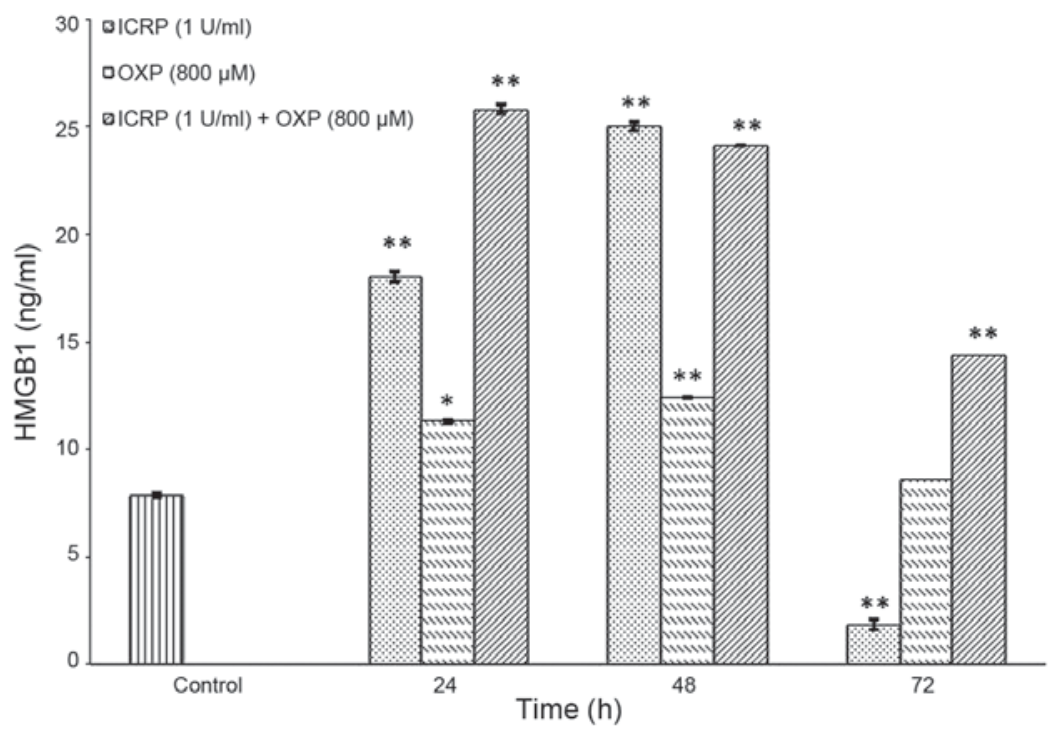

Figure 5. HMGB1 release by dying B16F10 cells following treatment with ICRP, OXP, and ICRP + OXP, as assessed by ELISA. The results represent three experiments performed in triplicate and data are expressed as the mean \pm standard deviation. ${ }^{*} \mathrm{P}<0.05,{ }^{* * *} \mathrm{P}<0.001$ vs. control. HMGB1, high mobility group box 1; ICRP, IMMUNEPOTENT CRP; OXP, oxaliplatin.

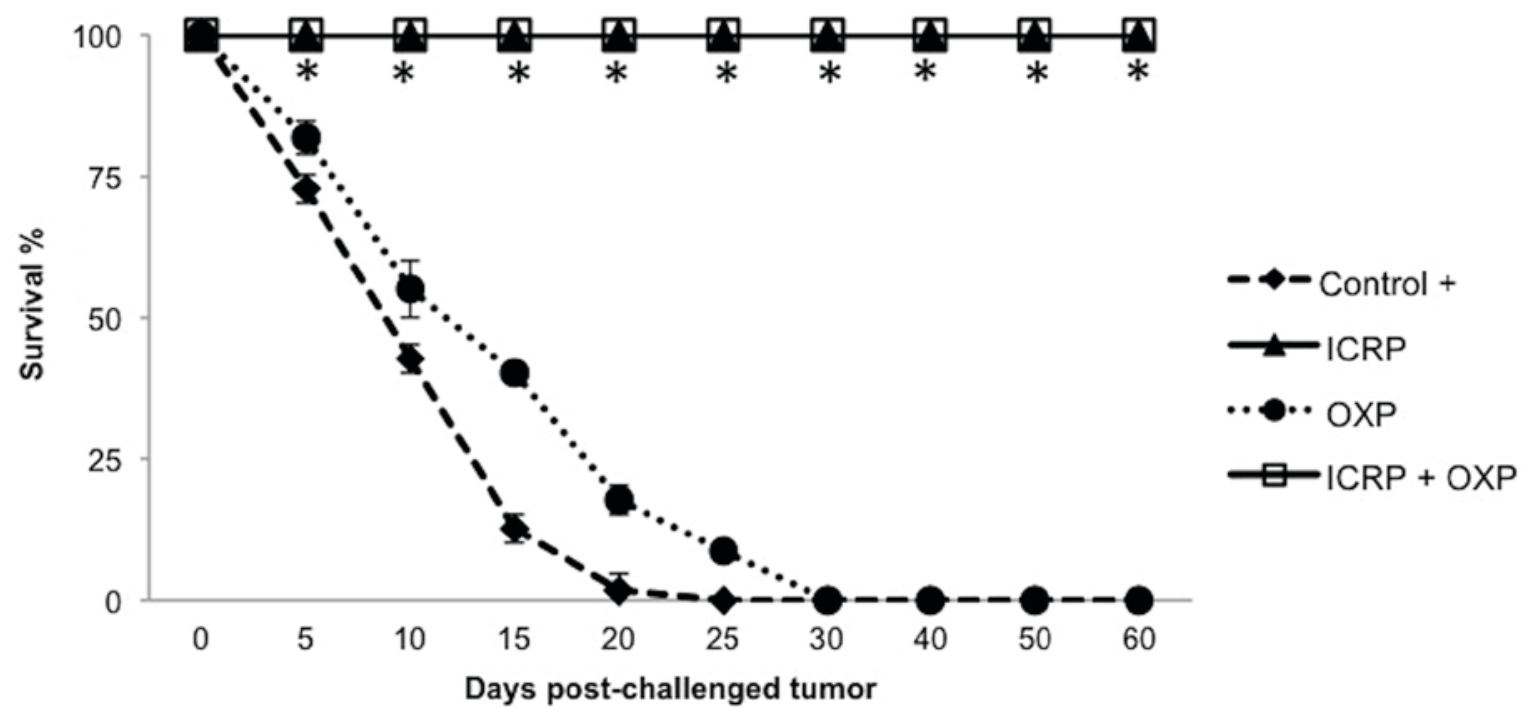

Figure 6. Effects of tumor-derived DAMP-rich cell lysates derived from B16F10 cells treated with ICRP, OXP, and ICRP + OXP in the prevention of melanoma. The tumor-derived DAMP-rich cell lysate-derived treatments of B16F10 cells were subcutaneously inoculated into C57BL/6 mice on the left flank. Mice were re-challenged with live B16F10 cells on the right flank. After 7 days, melanoma growth was evaluated. "P $<0.05$ vs. control. DAMP, damage-associated molecular pattern; ICRP, IMMUNEPOTENT CRP; OXP, oxaliplatin.

+ OXP treatments increased HMGB1 release at 24 and $48 \mathrm{~h}$ compared with the control $(\mathrm{P}<0.001 ;$ Fig. 5). Treatment with ICRP significantly increased the release of HMGB1 at $24 \mathrm{~h}$ $(\mathrm{P}<0.001)$ and $48 \mathrm{~h}(\mathrm{P}<0.001)$ compared with the control; however, it decreased at $72 \mathrm{~h}(\mathrm{P}<0.001$; Fig. 5). Treatment with OXP significantly increased the release of HMGB1 at $24 \mathrm{~h}(\mathrm{P}<0.05)$ and $48 \mathrm{~h}(\mathrm{P}<0.001)$ but decreased the release at $72 \mathrm{~h}$ compared with the control (Fig. 5). The treatment with ICRP + OXP significantly increased the release of HMGB1 at all the times evaluated $(\mathrm{P}<0.001)$ compared with the control. In the cell lysates, the presence of HSP70, HSP90 and HMGB1 was detected in the control treatment at all the time-points evaluated. HSP70 and HSP90 were detected in cells exposed to ICRP or ICRP + OXP treatments at 24,48 and $72 \mathrm{~h}$, but were not detected in cells exposed to OXP treatment at $72 \mathrm{~h}$. HMGB1 only was detected in cells exposed to ICRP treatment at $24 \mathrm{~h}$ (Fig. 4).

In vivo effects of tumor-derived DAMP-rich cell lysates derived from B16F10 cells treated with ICRP, OXP or ICRP + OXP in the prevention of melanoma. In vitro experiments demonstrated the cytotoxic effect and induction of DAMPs, which are characteristic of immunogenic cell death, following treatments with ICRP, OXP, or a combination of ICRP + OXP. To evaluate the immunogenicity of the immunogenic cell death induced by the treatments in vivo, anti-tumor vaccination experiments were performed in a mouse model. The tumor-derived DAMP-rich cell lysates derived from previous 
treatments of B16F10 cells with ICRP, OXP or a combination of ICRP + OXP were administered to mice prior to inoculation with live B16F10 cells. The results demonstrated that the ICRP and ICRP + OXP treatments prevented the development of melanoma growth. The tumor-derived DAMP-rich cell lysates from the OXP treatment did not protect against melanoma growth, but delayed mortality in the mice (30 days) compared with the control (20 days; Fig. 6).

\section{Discussion}

There has been increasing interest in the optimization of old and the identification of novel therapeutic agents with the capacity to generate anticancer immunity. Immunogenic cell death generated from antitumor treatments is one of the mechanisms through which these treatments elicit their tumor-targeting immune responses (41). The present study aimed to determine the potential of ICRP used in combination with chemotherapy to increase cytotoxicity against tumor cells and to induce molecules associated with immunogenic death, as novel therapeutic regimens that focus on a combination of strategies to trigger these mechanisms are in development.

The results of the present study demonstrated that treatment with ICRP was cytotoxic in B16F10 melanoma cells, and that the combination of ICRP treatment with OXP increased the rate of cell death. This was similar to results concerning the cytotoxic effects on cancer cells of ICRP treatment alone, which were identified previously by our group (37). It is important to note that in the present study, the treatments with ICRP or ICRP + OXP induced the release of several immunogenic molecules (CRT, ATP, HSP70, HSP90 and HMGB1) in vitro. The presence of these molecules, when induced by anthracycline treatment in colon cancer CT26 cells, melanoma B16F10 cells or fibrosarcoma MCA205 cells, has been associated with the prevention of tumor growth (42-44). HMGB1 was not detected in the supernatant by western blot assay, potentially due to the sensitivity of the antibody used; but when examined with an ELISA kit with high sensitivity the release of HMGB1 was detected. Similar results for human HMBG1 were demonstrated by Nowak et al (45), where concentrations of $150 \mathrm{ng} / \mathrm{ml}$ were detected by ELISA and western blot, but lower concentrations (1 or $15 \mathrm{ng} / \mathrm{ml}$ ) were not detected by western blot; only by ELISA.

OXP treatment has been suggested to induce the release of DAMPs (CRT, ATP, HMGB1 and type I interferon) in several cancer cell lines, and is considered to be an inductor agent of ICD $(27,31)$. To the best of our knowledge, studies examining the effect of immunogenic cell death induced by OXP on the B16F10 cancer cell line, which is poorly immunogenic, had not yet been performed. The results of the present study indicated that oxaliplatin induced the exposure of CRT and the release of ATP and HMGB1, but did not induce the release of HSP70 and HSP90 in the B16F10 cancer cell line. Compounds with the capability to induce the release of HSP70, HSP90, ATP and HMGB1 have been demonstrated to prevent tumor growth $(30-34,46,47)$. In addition, Chen et al (24) suggested that treatment with shikonin in B16F10 cells induced exposure of CRT and the release of HSP70, HSP90, GRP78 and HMGB1 in vitro, and allowed the maturation of dendritic cells; and shikonin tumor-derived cell lysate-loaded dendritic cell vaccines were indicated to induce retardation of tumor growth and to increase the survival rate of mice. Similar results were obtained in the present study, where tumor cell lysates derived from B16F10 cells treated with ICRP or ICRP + OXP administered to mice were demonstrated to prevent melanoma growth induced by injection with live B16F10 cells, indicating the potential of these treatments to induce immunogenic cell death. OXP-induced immunogenic death of colon cancer cells has been demonstrated in murine and human cell lines, and OXP prevented the formation of tumors $(4,27)$. However; in the present study this was not observed, suggesting that it is necessary for OXP to induce the additional release of HSP70 and HSP90 in B16F10 cells in order to generate immunogenic cell death, similar to the aforementioned treatments $(30-34,48,49)$. Depending on the type of cell death inducer involved, tumor cells may expose or release factors that affect their uptake (CRT), maturation (HSP90) or antigen presentation by dendritic cells (HMGB1) (46). Studies investigating the induction of immunogenic cell death by anthracyclines, OXP or ionizing radiation suggest that these effects require the presence of DAMPs and their corresponding receptors on antigen-presenting cells for complete therapeutic success (46).

It has been demonstrated that in cancer patients or whole tumor cells, treatment with drugs including oxaliplatin or doxorubicin (30-34) or physical procedures $(47,50-52)$ may induce a specific immune response through tumor antigens that have been exposed to dendritic cells, together with DAMP priming and the activation of naïve $\mathrm{T}$ cells to target tumors (53).

Although additional studies are necessary to understand the mechanisms underlying the prevention of melanoma growth, the present study demonstrated that IMMUNEPOTENT CRP, currently used in Mexico as an adjuvant to the immune system, may be used in combination with chemotherapy as a potential agent to increase the action of antitumor drugs by inducing immunogenic cell death to eliminate residual cancer cells in patients, and may generate the development of a whole tumor vaccine.

\section{Acknowledgements}

The present study was supported by the Laboratory of Immunology and Virology, Biological Sciences Faculty, Autonomous University of Nuevo Leon, in collaboration with 'Red temática de Inmunología en Cancer y Enfermedades Infecciosas' (grant no. 253053; CONACYT).

\section{References}

1. Tesniere A, Panaretakis T, Kepp O, Apetoh L, Ghiringhelli F, Zitvogel L and Kroemer G: Molecular characteristics of immunogenic cancer cell death. Cell Death Differ 15: 3-12, 2007.

2. Tesniere A, Apetoh L, Ghiringhelli F, Joza N, Panaretakis T, Kepp O, Schlemmer F, Zitvogel L and Kroemer G: Immunogenic cancer cell death: A key-lock paradigm. Curr Opin Immunol 20: 504-511, 2008.

3. Kroemer G, Galluzzi L, Kepp O and Zitvogel L: Immunogenic cell death in cancer therapy. Annu Rev Immunol 31: 51-72, 2013.

4. Obeid M, Tesniere A, Ghiringhelli F, Fimia GM, Apetoh L, Perfettini JL, Castedo M, Mignot G, Panaretakis T, Casares N, et al: Calreticulin exposure dictates the immunogenicity of cancer cell death. Nat Med 13: 54-61, 2007. 
5. Obeid M, Panaretakis T, Joza N, Tufi R, Tesniere A, van Endert P, Zitvogel $L$ and Kroemer G: Calreticulin exposure is required for the immunogenicity of gamma-irradiation and UVC light-induced apoptosis. Cell Death Differ 14: 1848-1850, 2007.

6. Panaretakis T, Joza N, Modjtahedi N, Tesniere A, Vitale I, Durchschlag M, Fimia GM, Kepp O, Piacentini M, Froehlich KU, et al: The co-translocation of ERp57 and calreticulin determines the immunogenicity of cell death. Cell Death Differ 15: 1499-1509, 2008

7. Panaretakis $\mathrm{T}$, Kepp O, Brockmeier U, Tesniere A, Bjorklund AC, Chapman DC, Durchschlag M, Joza N, Pierron G, van Endert P, et al: Mechanisms of pre-apoptotic calreticulin exposure in immunogenic cell death. EMBO J 28: 578-590, 2009.

8. Krysko DV, Garg AD, Kaczmarek A, Krysko O, Agostinis P and Vandenabeele P: Immunogenic cell death and DAMPs in cancer therapy. Nat Rev Cancer 12: 860-875, 2012.

9. Aymeric L, Apetoh L, Ghiringhelli F, Tesniere A, Martins I, Kroemer G, Smyth MJ and Zitvogel L: Tumor Cell Death and ATP release prime dendritic cells and efficient anticancer immunity. Cancer Res 70: 855-858, 2010.

10. Ghiringhelli F, Apetoh L, Tesniere A, Aymeric L, Ma Y, Ortiz C, Vermaelen K, Panaretakis T, Mignot G, Ullrich E, et al: Activation of the NLRP3 inflammasome in dendritic cells induces IL-1beta-dependent adaptive immunity against tumors. Nat Med 15: 1170-1178, 2009.

11. Garg AD, Krysko DV, Verfaillie T, Kaczmarek A, Ferreira GB, Marysael T, Rubio N, Firczuk M, Mathieu C, Roebroek AJ, et al: A novel pathway combining calreticulin exposure and ATP secretion in immunogenic cancer cell death. EMBO J 31: 1062-1079, 2012.

12. Martins I, Tesniere A, Kepp O, Michaud M, Schlemmer F, Senovilla L, Séror C, Métivier D, Perfettini JL, Zitvogel L and Kroemer G: Chemotherapy induces ATP release from tumor cells. Cell Cycle 8: 3723-3728, 2009.

13. Martins I, Wang Y, Michaud M, Ma Y, Sukkurwala AQ, Shen S, Kepp O, Métivier D, Galluzzi L, Perfettini JL, et al: Molecular mechanisms of ATP secretion during immunogenic cell death. Cell Death Differ 21: 79-91, 2014.

14. Srivastava P: Interaction of heat shock proteins with peptides and antigen presenting cells: Chaperoning of the innate and adaptive immune responses. Annu Rev Immunol 20: 395-425, 2002

15. Srivastava P: Roles of heat-shock proteins in innate and adaptive immunity. Nat Rev Immunol 2: 185-194, 2002.

16. Schmitt E, Gehrmann M, Brunet M, Multhoff $G$ and Garrido C: Intracellular and extracellular functions of heat shock proteins: Repercussions in cancer therapy. J Leukoc Biol 81: 15-27, 2007.

17. Kepp O, Tesniere A, Schlemmer F, Michaud M, Senovilla L, Zitvogel L and Kroemer G: Immunogenic cell death modalities and their impact on cancer treatment. Apoptosis 14: 364-375, 2009.

18. Bianchi ME and Manfredi AA: High-mobility group box 1 (HMGB1) protein at the crossroads between innate and adaptive immunity. Immunol Rev 220: 35-46, 2007.

19. Yamazaki T, Hannani D, Poirier-Colame V, Ladoire S, Locher C, Sistigu A, Prada N, Adjemian S, Catani JP, Freudenberg M, et al: Defective immunogenic cell death of HMGB1-deficient tumors: Compensatory therapy with TLR4 agonists. Cell Death Differ 21: 69-78, 2014.

20. Fredly H, Ersvær E, Gjertsen BT and Bruserud O: Immunogenic apoptosis in human acute myeloid leukemia (AML): Primary human AML cells expose calreticulin and release heat shock protein (HSP) 70 and HSP90 during apoptosis. Oncol Rep 25: $1549-1556,2011$

21. D'Eliseo D, Manzi L and Velotti F: Capsaicin as an inducer of damage-associated molecular patterns (DAMPs) of immunogenic cell death (ICD) in human bladder cancer cells. Cell Stress Chaperones 18: 801-808, 2013.

22. Garg AD, Krysko DV, Vandenabeele P and Agostinis P: Hypericin-based photodynamic therapy induces surface exposure of damage-associated molecular patterns like HSP70 and calreticulin. Cancer Immunol Immunother 61: 215-221, 2012.

23. Fucikova J, Kralikova P, Fialova A, Brtnicky T, Rob L, Bartunkova J and Spísek R: Human tumor cells killed by anthracyclines induce a tumor-specific immune response. Cancer Res 71: 4821-4833, 2011

24. Chen HM, Wang PH, Chen SS, Wen CC, Chen YH, Yang WC and Yang NS: Shikonin induces immunogenic cell death in tumor cells and enhances dendritic cell-based cancer vaccine. Cancer Immunol Immunother 61: 1989-2002, 2012.
25. Zhao T, Ren H, Jia L, Chen J, Xin W, Yan F, Li J, Wang X, Gao S, Qian D, et al: Inhibition of HIF-1 $\alpha$ by PX-478 enhances the anti-tumor effect of gemcitabine by inducing immunogenic cell death in pancreatic ductal adenocarcinoma. Oncotarget 6 : 2250-2262, 2015.

26. Menger L, Vacchelli E, Adjemian S, Martins I, Ma Y, Shen S, Yamazaki T, Sukkurwala AQ, Michaud M, Mignot G, et al: Cardiac glycosides exert anticancer effects by inducing immunogenic cell death. Sci Transl Med 4: 143ra99, 2012.

27. Tesniere A, Schlemmer F, Boige V, Kepp O, Martins I, Ghiringhelli F, Aymeric L, Michaud M, Apetoh L, Barault L, et al: Immunogenic death of colon cancer cells treated with oxaliplatin. Oncogene 29: 482-491, 2010

28. Calvet CY, Famin D, André FM and Mir LM: Electrochemotherapy with bleomycin induces hallmarks of immunogenic cell death in murine colon cancer cells. Oncoimmunology 3 : e28131, 2014

29. Obeid M, Tesniere A, Panaretakis T, Tufi R, Joza N, van Endert P, Ghiringhelli F, Apetoh L, Chaput N, Flament C, et al: Ecto-calreticulin in immunogenic chemotherapy. Immunol Rev 220: 22-34, 2007

30. Dudek AM, Garg AD, Krysko DV, De Ruysscher D and Agostinis P: Inducers of immunogenic cancer cell death. Cytokine Growth Factor Rev 24: 319-333, 2013

31. Bezu L, Gomes-de-Silva LC, Dewitte H, Breckpot K, Fucikova J, Spisek R, Galluzzi L, Kepp O and Kroemer G: Combinatorial strategies for the induction of immunogenic cell death. Front Immunol 6: 187, 2015.

32. Garg AD, Galluzzi L, Apetoh L, Baert T, Birge RB, Bravo-San Pedro JM, Breckpot K, Brough D, Chaurio R, Cirone M, et al: Molecular and translational classifications of DAMPS in immunogenic cell death. Front Immunol 6: 588, 2015.

33. Pol J, Vacchelli E, Aranda F, Castoldi F, Eggermont A, Cremer I, Sautès-Fridman C, Fucikova J, Galon J, Spisek R, et al: Trial Watch: Immunogenic cell death inducers for anticancer chemotherapy. Onco Immunology 4: e1008866, 2015.

34. Inoue $\mathrm{H}$ and Tani $\mathrm{K}$ : Multimodal immunogenic cancer cell death as a consequence of anticancer cytotoxic treatments. Cell Death Differ 21: 39-49, 2014

35. Franco-Molina MA, Mendoza-Gamboa E, Zapata-Benavides $P$ Vera-García ME, Castillo-Tello P, García de la Fuente A, Mendoza RD, Garza RG, Támez-Guerra RS and Rodríguez-Padilla C: IMMUNEPOTENT CRP (bovine dialyzable leukocyte extract) adjuvant immunotherapy: A phase I study in non-small cell lung cancer patients. Cytotherapy 10: 490-496, 2008.

36. Franco-Molina MA, Mendoza-Gamboa E, MirandaHernández D, Zapata-Benavides $\mathrm{P}$, Castillo-León L, Isaza-Brando C, Tamez-Guerra RS and Rodríguez-Padilla C: In vitro effects of bovine dialyzable leukocyte extract (bDLE) in cancer cells. Cytotherapy 8: 408-414, 2006.

37. Franco-Molina MA, Mendoza-Gamboa E, Zapata-Benavides $\mathrm{P}$, Castillo-Tello $\mathrm{P}$, Isaza-Brando $\mathrm{CE}$, Zamora-Avila $\mathrm{D}$, Rivera-Morales LG, Miranda-Hernández DF, Sierra-Rivera CA, Vera-García ME, et al: Antiangiogenic and antitumor effects of IMMUNEPOTENT CRP in murine melanoma. Immunopharmacol Immunotoxicol 32: 637-646, 2010.

38. Franco-Molina MA, Mendoza-Gamboa E, Castillo-León L, Tamez-Guerra RS and Rodríguez-Padilla C: Bovine dialyzable leukocyte extract modulates the nitric oxide and pro-inflammatory cytokine production in lipopolysaccharide-stimulated murine peritoneal macrophages in vitro. J Med Food 8: 20-26, 2005.

39. Mendoza-Gamboa E, Franco-Molina MA, Zapata-Benavides $P$, Castillo-Tello P, Vera-García ME, Tamez-Guerra RS and Rodríguez-Padilla C: Bovine dialyzable leukocyte extract modulates AP-1 DNA-binding activity and nuclear transcription factor expression in MCF-7 breast cancer cells. Cytotherapy 10: 212-219, 2008.

40. Franco-Molina MA, Mendoza-Gamboa E, Castillo-León L, Tamez-Guerra RS and Rodríguez-Padilla C: Bovine dialyzable leukocyte extract protects against LPS-induced, murine endotoxic shock. Int Immunopharmacol 4: 1577-1586, 2004

41. Zitvogel L, Kepp O, Senovilla L, Menger L, Chaput N and Kroemer G: Immunogenic tumor cell death for optimal anticancer therapy: The calreticulin exposure pathway. Clin Cancer Res 16: 3100-3104, 2010.

42. Cao C, Han Y, Ren Y and Wang Y: Mitoxantrone-mediated apoptotic B16-F1 cells induce specific anti-tumor immune response. Cell Mol Immunol 6: 469-475, 2009. 
43. Tongu M, Harashima N, Yamada T, Harada T and Harada M: Immunogenic chemotherapy with cyclophosphamide and doxorubicin against established murine carcinoma. Cancer Immunol Immunother 59: 769-777, 2010.

44. Perez CA, Fu A, Onishko H, Hallahan DE and Geng L: Radiation induces an antitumor immune response to mouse melanoma. Int J Radiat Biol 85: 1126-1136, 2009.

45. Nowak P, Abdurahman S, Lindkvist A, Troseid M and Sönnerborg A: Impact of HMGB1/TLR ligand complexes on HIV-1 replication: Possible role for flagellin during HIV-1 infection. Int J Microbiol 2012: 263836, 2012.

46. Skitzki JJ, Repasky EA and Evans SS: Hyperthermia as an immunotherapy strategy for cancer. Curr Opin Investig Drugs 10 550-558, 2009

47. Shi H, Cao T, Connolly JE, Monnet L, Bennett L, Chapel S, Bagnis C, Mannoni P, Davoust J, Palucka AK and Banchereau J: Hyperthermia enhances CTL cross-priming. J Immunol 176: 2134-2141, 2006

48. Tamura Y, Peng P, Liu K, Daou M and Srivastava PK: Immunotherapy of tumors with autologous tumor-derived heat shock protein preparations. Science 278: 117-120, 1997.
49. Vanaja DK, Grossmann ME, Celis E and Young CY: Tumor prevention and antitumor immunity with heat shock protein 70 induced by 15 -deoxy-delta12,14-prostaglandin $\mathrm{J} 2$ in transgenic adenocarcinoma of mouse prostate cells. Cancer Res 60: 4714-4718, 2000

50. Chiang CL, Ledermann JA, Rad AN, Katz DR and Chain BM: Hypochlorous acid enhances immunogenicity and uptake of allogeneic ovarian tumor cells by dendritic cells to cross-prime tumor-specific $\mathrm{T}$ cells. Cancer Immunol Immunother 55: 1384-1395, 2006.

51. Chiang CL, Ledermann JA, Aitkens E, Benjamin E, Katz DR and Chain BM: Oxidation of ovarian epithelial cancer cells by hypochlorous acid enhances immunogenicity and stimulates $\mathrm{T}$ cells that recognize autologous primary tumor. Clin Cancer Res 14: 4898-4907, 2008.

52. Chiang CL, Coukos G and Kandalaft LE: Whole tumor antigen vaccines: where are we? Vaccines (Basel) 3: 344-372, 2015.

53. Zitvogel L, Apetoch L, Ghiringhelli F and Kroemer G: Immunological aspects of cancer chemotherapy. Nat Rev Immunol 8: 59-73, 2008. 